\title{
PERTUKARAN sosial DalaM TRADIsI paNTaWAN BUNTING pada suKu BaNgsa BesemaH DI KOTA pAGARALAM PROUINSI SUMATERA SELATAN
}

\author{
SOCIAL EXCHANGE IN THE TRADITION OF PANTAWAN \\ BUNTING OF BESEMAH ETHNIC GROUP AT PAGARALAM, \\ PROVINCE OF SOUTH SUMATERA
}

\author{
Rois Leonard Arios \\ Balai Pelestarian Nilai Budaya Sumatera Barat \\ Jl. Raya Belimbing No. 16 A Kuranji Padang \\ E-mail: rolear72@yahoo.co.id
}

Naskah Diterima: 10 Juni 2019 Naskah Direvisi: 1 September $2019 \quad$ Naskah Disetujui : 28 September 2019

DOI: 10.30959/patanjala.v11i3.537

\begin{abstract}
Abstrak
Tulisan ini bertujuan menganalisis proses pertukaran sosial yang terjadi pada tradisi pantawan bunting pada suku bangsa Besemah di Kota Pagaralam. Tradisi ini merupakan bagian dari upacara perkawinan di mana pengantin (bunting) menghadiri undangan para kerabat dan tetangga untuk menikmati hidangan makanan dan minuman sehari sebelum acara sedekahan. Penelitian dilakukan dengan metode penelitian kualiatatif dengan data utama diperoleh melalui wawancara, pengamatan, dan studi literatur. Berdasarkan analisa data disimpulkan bahwa pemberian makanan dan minuman kepada pengantin (bunting) merupakan proses timbal balik antarkedua belah pihak. Si pemberi (tuan rumah) tidak berharap akan mendapatkan balasan finansial melainkan berupa keterlibatan si pengantin dalam aktivitas adat keluarga si pemberi
\end{abstract}

Kata kunci: Pertukaran sosial, tradisi, pantawan bunting.

\begin{abstract}
This paper aims to analyze the process of social exchange that occurs in the tradition of pantawan bunting in the besemah ethnic groups in the City of Pagaralam. This tradition is part of a wedding ceremony where the bride and groom (bunting) attend the invitation of relatives and neighbors to enjoy food and drink a day before the almsgiving event (sedekahan). The study was conducted with qualitative research methods with main data obtained through interviews, observations, and literature studies. Based on the analysis of the data it was concluded that the invitation to enjoy meals to the bride and groom (bunting) was a reciprocal process between the two parties. The giver (host) does not expect to get a financial reward but rather encourages the bride's involvement in the traditional activities of the giver's family.
\end{abstract}

Keywords: Social exchange, tradition, pantawan bunting

\section{A. PENDAhuluan}

Suku bangsa Besemah memandang adat perkawinan merupakan sebuah proses yang sakral dalam menjalin hubungan kekeluargaan dua belah pihak. Proses tersebut dilakukan melalui kompromi hingga tujuan tercapai. Secara tradisional suku bangsa Besemah hanya mengenal adat perkawinan padu kule, yaitu adat yang mengacu kepada prinsip patrilineal dan 
patrilokal. Namun demikian, ada juga berkembang dengan menggunakan adat semenda atau disebut juga teambik anak yang mengacu pada prinsip matilineal dan matrilokal (Suan, dkk. 2007a: 10).

Dalam upaya menjalin silahturahmi antara kerabat pihak perempuan dengan pihak laki-laki, setiap pengantin harus melalui tradisi pantawan bunting yaitu proses yang dilalui oleh calon pengantin atau pengantin baru yang disebut bunting. Prosesi ini dilakukan beberapa hari sebelum dan saat pelaksanaan sedekah (hajatan) pernikahan pada suku bangsa Besemah. Menurut Asrin, Sudjarwo, dan Pargito (2016: 24-26), prosesi adat perkawinan Besemah terdiri dari 6 tahapan yaitu miare tunang, nolong tunang, ngalih panggilan atau ngalih tutughan, nentukan waktu pelaksanaan perkawinan, netak aghi malam, dan pelaksanaan hajatan. Tradisi pantawan bunting dilaksanakan sehari atau 3 hari sebelum pelaksanaan hajatan. Biasanya sehari sebelum hajatan dilakukan kegiatan memasak makanan dan minuman untuk para tamu (hari bemasak). Pada saat hari bemasak inilah pantawan bunting dilaksanakan.

Menurut Bastari Suan (wawancara, via telepon 5 Maret 2018), bentuk pantawan bunting tergantung pada bentuk sedekahan yang terbagi dalam tiga bentuk berdasarkan besar kecilnya bentuk pesta perkawinan, yaitu sedekah besa atau kule agung, sedang, dan kecik. Jika pesta perkawinannya besar (sedekah besa atau kule agung) ditandai dengan memotong kerbau, maka pantawan bunting akan dilaksanakan oleh hampir seluruh kerabat dan penduduk desa tempat tinggal sekitar pengantin laki-laki dan perempuan. Jika pestanya tidak terlalu besar yang diistilahkan sedekahan sedang dan hanya memotong kambing, maka pantawan bunting hanya dilakukan oleh kerabat dekat dan beberapa tetangga dekat pengantin laki-laki dan perempuan. Adapun apabila pestanya kecil atau tidak dirayakan sama sekali atau hanya ditandai dengan memotong ayam, maka pantawan bunting hanya dilakukan oleh kerabat dekat kedua pengantin atau tetangga pihak laki-laki dan perempuan.

Proses interaksi merupakan proses memberi dan menerima yang secara kasat mata tidak terlihat. Gunawardi (2016: 2-3) misalnya secara umum menggambarkan bagaimana kegiatan tolong-menolong pada adat perkawinan pada masyarakat Aceh yang sebagian kebutuhan pesta ditanggung oleh pribadi atau beberapa orang tetangga sehingga tuan rumah terbantu. Demikian juga tulisan Ambarwati dan Hesti Asriwandari (2014: 2-3) menggambarkaan tradisi Sinoman pada adat pernikahan suku bangsa Jawa di Rokan Hulu. Pada tradisi itu digambarkan bahwa para tetangga secara sukarela memberikan sumbangan kepada tuan rumah pelaksana pesta berupa uang atau kebutuhan lainnya.

Berdasarkan dua tulisan tersebut terlihat ada proses memberi dan menerima yang terjadi antara kedua belah pihak seperti halnya pantawan bunting pada suku bangsa Besemah. Dari dua tulisan tersebut dijelaskan bahwa secara ekonomi memberi bantuan kepada tetangga dalam aktivitas sosial maupun budaya tentu menambah beban pemberi bantuan. Namun demikian, secara sosial baik si pemberi dan penerima sama-sama diuntungkan dengan proses tersebut, yang oleh Homanns, sebagaimana dikutip Scott (2012: 243-245) disebut pertukaran sosial.

Mengacu pada teori pertukaran sosial, dapat dipertanyakan bagaimana tradisi pantawan bunting dapat dipahami sebagai proses timbal balik antara dua pihak yang berinteraksi pada suku bangsa Besemah? Dengan pertanyaan tersebut, tulisan ini ingin menggambarkan pantawan bunting sebagai sebuah pertukaran sosial yang bertahan di masyarakat suku bangsa Besemah.

George C. Homans memandang perilaku sosial sebagai pertukaran aktivitas dan kepentingan yang dimiliki oleh masing-masing individu. Teori pertukaran Homans adalah interaksi antar individu yang melakukan pertukaran kepentingan 
dengan hukum dasar "imbalan dan keuntungan yang didapat oleh individu yang melakukan pertukaran itu". Pertukaran sosial yang terjadi di masyarakat tidak selalu bersifat statis, karena tidak selamanya individu mendapatkan keuntungan dari proses pertukaran sosial, maka dari itu perlu dilakukan proposisi. Homans menegaskan bahwa perilaku sosial individu dapat dijelaskan berdasarkan beberapa proposisi psikologi (kejiwaan) dan motivasi individu tersebut. Proposisi dipandang sebagai dasar pertimbangan rasional atau kalkulasi ekonomis. Ia tidak tertarik kepada kesadaran atau kepada berbagai jenis struktur dan lembaga berskala besar yang diperhatikan oleh sebagian besar sosiolog. Premisnya ialah bahwa interaksi-interaksi mungkin berlanjut bila ada pertukaran penghargaan dan sebaliknya. Interaksiinteraksi yang merugikan bagi salah satu atau kedua belah pihak kecil kemungkinannya untuk berlanjut (Ritzer dan Smart, 2012: 515-517).

Ciri terpenting dari teori pertukaran sosial terletak pada analisisnya mengenai hubungan sosial menurut cost and reward. Homans menjelaskan bahwa interaksi sosial yang ada di masyarakat terjadi karena pertukaran sosial. Pertukaran sosial menurutnya adalah suatu keadaan di mana orang-orang terus melakukan apa yang mereka rasakan mendapat penghargaan di masa silam dan sebaliknya, mereka akan berhenti melakukan apa yang terbukti merugikan di masa silam. Scott (2012: 243-245) menjelaskan pemikiran Homans tentang pertukaran sosial bahwa tidak ada interaksi yang bertahan jika partisipan tidak mendapat untung. Jika interaksi tersebut merugikan, maka partisipan (aktor) akan mengundurkan diri dan mencari interaksi lainnya yang lebih menguntungkan. Pada masa silam atau jaman purba mereka melakukan pertukaran dengan cara menukarkan barang yang mereka miliki dengan barang apa yang mereka inginkan atau biasa disebut barter, hanya saja pada masa kini pertukaran yang terjadi tidak selalu dalam bentuk barang yang bisa dilihat. Keuntungan (profit) yang dicari partisipan atau masyarakat tidak sebatas hal-hal yang bersifat finansial, tetapi ingin mengamankan dirinya dalam berinteraksi seperti pengakuan, loyalitas, dukungan politik, pengetahuan, jasa, rasa bahagia, rasa bangga, kepuasan rohani, kepuasan batin dan lain sebagainya.
Damsar
(2015:
155-160)

merumuskan pemikiran para ahli teori pertukaran sosial seperti Homans, Blau, Emerson, Thibout, dan Kelly dalam 3 asumsi yaitu: 1) manusia sebagai makhluk rasional yang memperhitungkan untung dan rugi, 2) pertukaran hanya dapat berlangsung jika ada interaksi, 3) transaksi terjadi jika para aktor mendapat keuntungan.

\section{B. METODE PENELITIAN}

Penelitian ini menggunakan pendekatan kualitatif yang bukan sekedar menjelaskan fakta tetapi juga proses dan makna dibalik fakta tersebut (Bungin. 2007: 144). Pengumpulan data dilakukan melalui studi pustaka dan wawancara. Informan yang diwawancara berjumlah 11 orang yang berasal dari unsur lembaga adat Besemah di Kota Pagaralam, pelaksana hajatan, pelaksana pantawan, dan pemerhati budaya Besemah di Kota Palembang.

Data juga diperoleh melalui pengamatan dengan terlibat langsung pada pelaksanaan pantawan bunting di Kecamatan Dempo Selatan Kota Pagaralam 20-22 Juni 2018. Data yang diperoleh selanjutnya divalidasi melalui proses triangulasi dengan membandingkan data wawancara, literatur, dan pengamatan serta konfirmasi ke informan hingga data tersebut valid (Afrizal, 2014: 167). Data yang sudah valid selanjutnya dianalisa dengan pendekatan logika induktif hingga menghasilkan kesimpulan umum (Mulyana, 2008: 157). 


\section{HASIL DAN BAHASAN 1. Wilayah Budaya Besemah}

Besemah merupakan nama suku bangsa sekaligus wilayah kebudayaan (jagad Besemah). Kata Besemah berasal dari kata "semah" dan mendapat awalan kata "be-“. "Semah" adalah nama ikan yang ditemui di sungai wilayah Kota Pagaralam. Sedangkan awal "be-" berarti ada atau memiliki. Dengan demikian pengertian besemah menjadi memiliki ikan semah. Dalam mitologi Atung Bungsu, diceritakan Puteri Kinantan Buwih (istri Atung Bungsu) membawa ikan semah dari sungai, sejak saat itu daerah tersebut dinamai Besemah (ada ikan semah) (Suan, dkk., 2007b: 25-28).

Dengan mengutip berbagai sumber, Arios (2014: 187) membagi wilayah kebudayaan Besemah menurut konsep orang Besemah yaitu:

"[...] meliputi Rurah Besemah Ayik Keghuh (Daerah Besemah Air Keruh), Rurah Gumay Tige Jughu (LahatBandaragung), Rurah Besemah Libagh (Daerah Besemah Lebar), Rurah Besemah Palas (Daerah Palas Besemah di Lampung Selatan), Rurah Besemah Ulu Alas di Bengkulu Selatan, Rurah Besemah Ulu Inim (Daerah Semende Daghat - Semende Darat), Rurah Besemah Ulu Lintah (Daerah Besemah Ulu Lintang Kecamatan Jaray Kabupaten Lahat), Rurah Besemah Ulu Lawas (Daerah Semende Lembak Ulu Lawas Kecamatan Pulau Beringin Kabupaten Ogan Komering Ulu Selatan), dan Rurah Besemah Ulu Manak (Daerah Besemah Ulu Manak Kecamatan Tanjung Sakti)."

Menurut penelitian Collins sebagaimana dikutip oleh Sakai (2017), suku bangsa Besemah merupakan salah satu dari tiga suku bangsa bersaudara yaitu Diwe Gumay, Diwe Semidang dan Diwe Atung Bungsu yang turun dari langit ke Bukit Siguntang, sebuah bukit di
Palembang. Mereka merupakan leluhur tiga suku, yaitu Suku bangsa Gumay, Suku bangsa Semidang dan Suku bangsa Besemah, serta mendiami sebagian besar dataran tinggi di Sumatera Selatan. Pujang Ngawak Radje Njawe (paman Atung Bungsu) tidak punya keturunan, lalu dia mengangkat tiga anak yang kemudian terkenal dengan nama Tiga Diwe. Ketiga anak angkat tersebut yakni Serunting Sakti, Suke Mulung dan Puyang Atung Bungsu sendiri (Sakai, 2017: 25).

Secara administratif, wilayah kebudayaan Besemah meliputi Kota Pagaralam, Kabupaten Lahat, Kabupaten Empat Lawang, Kabupaten Muara Enim, dan Kabupaten Ogan Komering Ulus Selatan di Provinsi Sumatera Selatan. Khusus Kabupaten Lahat meliputi wilayah Kecamatan Jarai, Kecamatan Tanjung Sakti, daerah sekitar Kecamatan Kota Agung. Wilayah kebudayaan Besemah di Propinsi Bengkulu meliputi Kabupaten Kaur, Kabupaten Seluma, dan Kabupaten Bengkulu Selatan. Khusus di Kabupaten Kaur meliputi Kecamatan Padang Guci Hulu dan Kecamatan Padang Guci Hilir. Budaya Besemah juga terdapat di Propinsi Lampung yaitu di Kabupaten Lampung Selatan. Persebaran budaya Besemah hingga ke berbagai daerah di luar Kota Pagaralam diikuti dengan perubahan dan pembentukan identitas budaya baru di wilayah mereka masing-masing namun secara genealogis masih mengakui bahwa asal usul mereka berasal dari Pagaralam. Menurut berbagai literatur, semua wilayah itu pada masa kolonial Belanda memang termasuk bagian dari Kewedanaan Pasemah (Asrin, dkk. 2016).

\section{Konsep Pantawan}

Kata "pantawan" berasal dari kata "pantaw" (bahasa Besemah) yang bersinonim dengan kata-kata "ajak", "panggil", dan "undang". Kata "pantawa" setelah dibubuhi akhiran "-an" menjadi "pantawan".

Sebagian besar penulis yang mempublikasikan tulisannya melalui 
media internet baik situs pribadi maupun media lainnya, umumnya menuliskan kata "pantawan" dengan kata "pantauan". Menurut Suan (Wawancara, via telepon 5 Maret 2018) penulisan kata "pantau" tidak dikenal dalam kosa kata bahasa Besemah. Bahasa besemah hanya mengenal diftong "- $a w$ " dan bukan "au”, sehingga kata "pantau" harus ditulis "pantaw", "mantau" harus ditulis "mantaw" dan seterusnya.

Pengertian pantawan secara umum merupakan unsur adat, dan tradisi yang sekaligus menjadi salah satu identitas suku bangsa Besemah yang tersebar luas di Provinsi Sumatera Selatan, Provinsi Bengkulu, dan Provinsi Lampung. Secara khusus Kabupaten Kaur dan Kabupaten Bengkulu Selatan Provinsi Bengkulu sebagai wilayah persebaran suku bangsa Besemah. Tradisi pantawan masih tetap di laksanakan di Desa Lawang Agung Kecamatan Kedurang Bengkulu Selatan (Firnanda, 2018: 5). Pantawan mempunyai makna khusus, yaitu aktivitas para keluarga dalam suatu dusun mengajak/mengundang seorang atau orang-orang/keluarga atau rombongan untuk makan di rumahnya. Kehadiran orang-orang yang datang makan di rumah keluarga yang mengajak/mengundang makan itu disebut pantawan.

Konsep pantawan dapat dikelompokkan dalam pengertian sebagai berikut:

1. Kegiatan yang dilaksanakan oleh keluarga berupa mengajak/ mengundang makan;

2. Mengundang orang-orang untuk datang ke rumah keluarga yang sedekah itu. Orang yang ditugasi mengundang tersebut tukang pantawan;

3. Kegiatan menikmati hidangan yang disajikan

Dengan penjelasan tersebut dapat disimpulkan bahwa ada 4 yang menyandang sebutan pantawan, yaitu:

1. Orang yang mengajak/mengundang makan ke rumahnya;
2. Orang yang memenuhi ajakan/undangan makan dengan hadir di rumah keluarga yang mengundang makan;

3. Orang yang ditugasi mengajak/ mengundang orang-orang untuk datang ke rumah keluarga yang melakukan kenduri (sedekah); dan

4. Kegiatan/pekerjaan atau tugas mengajak/mengundang itu sendiri.

Suku bangsa Besemah mengenal beragam pantawan sesuai dengan kepentingan dan tujuan dari pantawan tersebut. Beberapa jenis pantawan tersebut adalah sebagai berikut:

\section{a. Pantawan Bunting (Mantaw Bunting)}

Pantawan bunting adalah menjamu pengantin oleh kerabat dan tetangga pengantin laki-laki dan perempuan. Pantawan bunting merupakan tradisi yang populer di antara berbagai jenis pantawan dalam adat Besemah. Bila pantawan bunting atau yang mantaw bunting ini dilakukan keluarga/kerabat pengantin lakilaki, maka yang dipantaw adalah bunting betine (pengantin perempuan). Demikian pula sebaliknya, bila yang mantaw bunting itu lingkungan keluarga/kerabat pengantin perempuan, maka yang dipantaw adalah bunting lanang (pengantin laki-laki).

Jika bunting yang dipantaw berasal dari dusun lain atau dari lain rurah ${ }^{1}$, maka yang mantaw akan lebih banyak atau hampir semua rumahtangga/keluarga dusun yang mantaw, tidak terbatas pada keluarga/kerabat dekat pengantin saja. Hal ini dilakukan karena pada hakikatnya, dusunlaman (kampung halaman) di Besemah itu merupakan satu keluarga besar, anak cucu dari moyang asal pendiri dusun.

Idealnya makanan (gulay) yang disajikan tuan rumah terhadap rombongan bunting yang akan dipantaw sangat terkait dengan tingkat hubungan kekerabatan antara keluarga yang mantaw dengan

1 Satuan wilayah permukiman yang tidak dibatasi oleh wilayah administratif tetapi oleh batas-batas alam seperti hutan atau sungai. 
keluarga bunting (pengantin) yang sedekah (hajatan). Jika hubungan kekerabatan satu nenek (sepuyang) yang disebut ninik besanak atau niningan-sanak (nenek/kakek bersaudara), maka disediakan gulay. Sementara itu, dengan kerabat jauh, misalnya puyang-besanak atau puyangansanak (kerabat nenek/kakek), cukup disediakan gulay ayam. Hubungan kerabat yang sangat jauh cukup dengan gulay telur itik. Jika tidak memiliki hubungan kekerabatan atau hubungan bertetangga (tumbang pelawanan), atau bukan "dalamghumah" (lain kampung namun sedusunlaman), hidangan yang disajikan bisa gulay apa saja, seperti terung, kentang, atau sayur-sayuran. Namun demikian, jika keluarga tersebut berniat memberikan hidangan yang lebih seperti gulay daging tidak jadi masalah. Dalam konteks ini, setiap pihak yang terlibat dalam pantawan, baik bunting yang dipantaw maupun yang mantaw harus memahami hubungan kekerabatan, termasuk tutur-sapa (tutughan) yang biasanya dikenalkan oleh pihak yang mantaw kepada bunting sambil menikmati hidangan. Saat bunting makan, saat itulah merupakan momen bagi kedua belah pihak untuk saling berdialog untuk lebih mengakrabkan kerabat bunting yang di-pantaw.

Jika karena suatu hal, misalnya keadaan cuaca, sempitnya waktu, sehingga bunting harus memilih satu atau dua dari beberapa rumah yang siap mantaw, maka pilihan bijak harus memilih rumah yang relatif lebih sederhana atau memilih keluarga yang relatif kurang mampu secara ekonomi dalam pandangan umum. Kalau bunting memilih rumah yang tampak lebih mewah atau memilih keluarga yang tampak lebih berada, maka akan timbul kesan bunting itu sumbung (sombong).

Tuan rumah akan sangat senang dan dihormati jika bunting dan rombongan menikmati hidangan yang disediakan (pacak ngambik ghase). Demikian juga sebaliknya jika bunting dan rombongan tidak menikmati hidangan, akan membuat tuan rumah kecewa dan berprasangka tidak baik terhadap bunting dan rombongan. Dengan kondisi ini, maka bunting dan rombongan harus bisa mengatur porsi makanan yang disantap agar bisa mencicipi hidangan di rumah yang siap untuk mantaw.

\section{b. Pantawan Simah (Mantaw Simah)}

Simah adalah rombongan besan yang menghadiri sedekahan (hajatan) di pihak besannya. Simah terdiri atas laki-laki dan perempuan, tua dan muda. Simah datang dijamu oleh tuan rumah yang melakukan pantawan bunting. Rombongan simah akan dijamu makan dan minum setelah rombongan bunting selesai dijamu oleh tuan rumah. Saat rombongan simah akan pulang, pihak pelaksana sedekahan memberikan ibatan berupa kue-kue yang tergolong makanan adat, seperti dudul padiberam (dodol ketan-itam), bajik atau belinak (wajik), juwadah basah dan juwadah lain-lain, guringan pisang sabe (pisang tembatu yang digoreng), dan lainlain. Selain ibatan, para simah juga diberi gulay daging yang dimasukkan ke seruas buluh berdiameter sekitar sebesar pergelangan tangan (jenis buluh kapal).

\section{c. Pantawan Kiaji (Njamu Kiaji)}

Kiaji adalah sebutan untuk orang yang sudah menunaikan ibadah haji. Kiajikiaji yang baru kembali dari tanah suci, dijamu makan oleh warga dusunnya dan oleh dusun-dusun tetangga (dusun-dusun dalam satu marga ${ }^{2}$ atau satu rurah). Para kiaji dalam satu dusun dipantaw secara bersamaan oleh tuan rumah setelah sebelumnya di-pantaw di masjid oleh imam masjid. Masa pantawan kiaji selama 40 hari sejak para kiaji sampai di dusunnya.

\footnotetext{
${ }^{2}$ Marga adalah satuan wilayah administratif sebelum berlakunya sisitem pemerintahan desa tahun 1979. Pada saat ini wilayah bekas marga di Besemah sudah menjadi kecamatan.
} 


\section{d. Pantawan Njenguk (Mantaw Jeme njenguk)}

Njenguk artinya melayat, mendatangi keluarga yang ditimpa musibah kematian. Para pelayat yang datang dari dusun lain dipantaw oleh penduduk dusun yang terkena musibah dengan memberi makan dan minum.

\section{e. Pantawan Riaye (Pantawan hari raya)}

Masyarakat suku bangsa Besemah mengenal beberapa tradisi dalam rangka menyambut hari raya Islam, yaitu hari raya Idul Fitri yang disebut riaye puwase atau lebaran puasa dan hari raya Idul Adha yang disebut riaye aji (hari raya haji). Pada kedua riaye, anggota keluarga menyiapkan hidangan di rumah masing-masing berupa hidangan nasi dan hidangan kue-kue. Makanan yang tergolong makanan adat pantawan riaye adalah tapay padiberam (tapai ketan hitam). Menghidangkan luntung (lontong) pada pantawan riaye menjadi tradisi di Dusun Lahat-tengah dan beberapa dusun di Rurah Besemah Ilir. Selain mantaw makan di rumah masingmasing, penduduk dusun kadang-kadang mengantar tampah (hidangan dengan tampa) ke masjid pada hari raya. Pada pantawan riaye, tuan rumah tidak mengundang orang datang ke rumahnya (satu dusun atau dari dusun lain) tetapi orang-orang terutama anak-anak akan datang ke rumah tersebut.

\section{f. Mantaw Anak belay}

Anakbelay adalah sebutan untuk perempuan dan keturunannya yang kawin menurut adat padu kule atau belaki atau kisah (kawin jujur). Jika pada suatu saat, anakbelay itu belaju (pulang/berkunjung) ke dusunlaman-nya, dusunlaman ibunya, mereka dipantaw oleh kerabat asal ibunya itu.

\section{g. Mantaw Tukang kah Balik}

Mantaw Tukang kah Balik adalah kegiatan pantawan yang dilakukan oleh kerabat dan tetangga pemilik rumah yang dibangun. Mantaw Tukang kah Balik dilakukan dengan menjamu makan tukang yang akan pulang setelah rumah selesai dikerjakan.

\section{h. Mantaw Jeme Mbalikkah Ingunan}

Pada suku bangsa Besemah ada tradisi pinjam-meminjam hewan, biasanya kerbau yang digunakan untuk membajak sawah. Ketika orang yang meminjam kerbau mengembalikan kepada pemiliknya, apabila dari dusun lain, orang yang mengembalikan kerbau itu dipantaw makan oleh tetangga atau kerabat dekat pemilik kerbau. Jenis pantawan ini disebut mantaw jeme mbalikkah ingunan (menjamu orang yang mengembalikan hewan peliharaan).

\section{i. Mantaw Simah Mende}

Tamu, mende, paretandang, adalah sebutan untuk tamu di Besemah. Tamu tersebut bisa saja kerabat dari dusun lain atau orang lain yang baru dikenal, atau rekan kerja, teman dan sebagainya. Tamu tersebut biasanya jarang bertemu atau sudah lama tidak pernah bertemu sehingga perlu dilakukan pantawan oleh kerabat dekat dari keluarga yang ditemui. Ini disebut dengan istilah umum "Mantaw Simah-mende".

\section{Pelaksanaan Pantawan Bunting}

Pelaksanaan sedekahan pernikahan pada orang Besemah dilakukan dua kali yaitu di keluarga pihak laki-laki dan pihak perempuan. Pihak yang terlebih dahulu mengadakan hajatan berdasarkan kesepakatan kedua belah pihak. Pihak yang pertama melaksanakan hajatan, akan melaksanakan pantawan pertama. Pihak pelaksana hajatan akan membentuk panitia kecil yang mengurus tempat, hidangan (makanan dan minuman), dan bidang pantawan (konsep pantawan yang dimaksud adalah petugas yang mengundang para tetangga, keluarga jauh, atau kenalan si tuan rumah).

Bagi masyarakat Besemah di Kota Pagaralam, undangan yang dianggap berharga adalah jika si pengundang (petugas pantawan) datang langsung ke rumah dan menyampaikan undangan 
secara lisan dan diberi kertas kecil (ukuran $1 / 4$ kertas kwarto) sebagai pengingat waktu dan tempat pesta (besuare). Jika ada yang mengundang dengan kertas undangan yang mewah, akan dianggap yang mengundang tersebut adalah orang tidak begitu dekat hubungan kerabat atau pertemanan. Jika masih memiliki hubungan keluarga atau teman dekat dan memberikan undangan cetak maka bisa membuat ketersinggungan si penerima sehingga cenderung tidak akan menghadiri undangan tersebut (wawancara dengan Kasim di Kota Pagaralam, 20 Juni 2018)

Proses awal pelaksanaan pantawan bunting dilakukan pada saat musyawarah keluarga luas masing-masing pengantin laki-laki dan pengantin perempuan terkait rencana pernikahan anak mereka. Musyawarah ini dipimpin oleh orang yang dianggap paling tua, baik dari segi umur maupun kedudukannya di keluarga tersebut. Ketika pantawan bunting disepakati untuk dilaksanakan, maka orang tua pengantin akan memberikan lemang sepanjang dua ruas bambu ke keluarga yang hadir dan keluarga lain yang disepakati sebagai tanda bahwa keluarga tersebut akan mantaw. Keluarga yang menerima lemang tersebut tidak boleh menolak kecuali ada alasan yang bisa diterima.

Berdasarkan pengamatan, pantawan bunting pertama dilaksanakan di keluarga pengantin laki-laki (bunting lanang) di Kecamatan Pagaralam Utara. Pada hari tersebut, pengantin perempuan (bunting betine) ditemani oleh gadis ngantat dan perwakilan keluarga bunting betine mendatangi rumah pengantin laki-laki pada pagi hari sekitar pukul 07.00. Lalu pengantin laki-laki membawa pengantin perempuan mengikuti proses pantawan bunting dengan mengunjungi kerabat dekat si pengantin laki-laki. Dalam hal ini, kerabat pengantin laki-laki akan mantaw si calon pengantin perempuan. Biasanya beberapa pertanyaan yang diajukan adalah latar belakang si calon pengantin perempuan seperti keluarga, pendidikan, dan pekerjaan. Namun pertanyaan tersebut sudah jarang diajukan karena jauh hari sebelumnya keluarga kerabat pengantin laki-laki sudah mendapat informasi tentang calon pengantin perempuan. Proses pantawan bunting yang dilaksanakan di keluarga laki-laki tersebut dilakukan dengan mengunjungi 20 rumah yang berada di sekitar rumah si laki-laki.

Pakaian yang dipakai kedua pengantin adalah pakaian adat Besemah namun tidak selengkap pada saat bersanding, seperti sepatu yang dipakai harus yang gampang dilepas, pakaian si perempuan juga harus yang tidak menghambat jalan karena banyaknya rumah yang harus didatangi. Demikian juga kondisi rumah yang umumnya rumah panggung yang menyulitkan jika menggunakan pakaian pengantin secara lengkap.

Sedekahan di keluarga pihak lakilaki relatif tidak begitu besar karena tidak dilakukan acara hajatan (identik dengan pesta atau resepsi perkawinan) kecuali melakukan pantawan bunting dan pertemuan antar kerabat dekat pihak lakilaki. Kegiatan yang lebih lengkap dengan tahapan hajatan pernikahan justru dilaksanakan keluarga pengantin perempuan.

Pantawan bunting di keluarga pengantin perempuan dilaksanakan bersamaan dengan hari bemasak. Pada hari bemasak kerabat maupun tamu udangan yang tidak bisa hadir pada hari resepsi, biasanya hadir pada hari bemasak dengan membawa ayam petelur (oleh masyarakat setempat disebut "ayam pramuka" karena memiliki warna yang menyerupai baju pramuka) dan ada juga yang membawa amplop berisi uang. ${ }^{3}$ Umumnya yang

\footnotetext{
3 Tamu-tamu yang hadir pada hari bemasak umumnya adalah kerabat atau tetangga yang tidak ikut mantaw bunting ataupun yang tidak bisa ikut bekerja membantu di hajatan tersebut. Konsekuensi yang harus diberikan adalah dengan memberikan bantuan berupa "ayam pramuka".
} 
datang pada hari ini adalah ibu-ibu tanpa didampingi suami, dan sebagian kecil yang datang didampingi suami. Jika yang datang hanya si suami akan membawa amplop.

Selanjutnya tamu yang hadir dipersilahkan memasuki ruangan yang telah disediakan untuk mencicipi hidangan berupa kue-kue dan minuman sebagai hidangan menyambut tamu. Proses ini termasuk pantawan yang idealnya tuan rumah harus menemani tamu untuk sekedar saling bercerita mengenai keadaan masing-masing (tuan rumah mantaw keadaan tamu). ${ }^{4}$ Selesai mencicipi hidangan kue-kue tersebut, selanjutnya tamu mengambil tempat di kursi-kursi yang telah disediakan di tempat hajatan menikmati hidangan utama berupa makanan dan minuman yang telah disediakan untuk para undangan.

Di lokasi hajatan proses ini berlangsung mulai dari pagi hari sekitar pukul 07.00 hingga sore hari, sekitar pukul 17.00. Tamu-tamu datang silih berganti membawa ayam pramuka. Ayam tersebut selanjutnya dikumpulkan untuk disembelih dan dimasak sebagai hidangan tamu-tamu. Waktu yang dibutuhkan para tamu di lokasi hajatan hanya sekitar 1 jam; mulai dari menikmati hidangan kue-kue, makan nasi dan lauk pauknya, bertegur sapa dengan undangan lainnya hingga berpamitan dengan tuan rumah. Pada hari itu para tamu tidak akan bertemu dengan bunting karena sedang melaksanakan pantawan.

Pantawan bunting dimulai pukul 07.00. Bunting lanang dan betine sudah mengenakan pakaian pengantin Besemah didampingi oleh gadis gantat dan bujang ngantat. Tugas bujang ngantat atau gadis ngantat adalah sebagai inang atau memberikan pelayanan atau mengurus keperluan kedua pengantin. Beberapa permintaan pengantin antara lain mengambilkan rokok, mengambilkan

\footnotetext{
${ }^{4}$ Pada saat pengamatan, hal ini tidak dilakukan oleh tuan rumah karena banyaknya tamu yang datang.
}

kopiah, mengambilkan air minum, mengambilkan jas dan lain-lain.

Pelayan bujang ngantat atau gadis ngantat akan memberikan pelayanan dengan cepat. Mereka bertugas selama tiga hari sebelum hari $\mathrm{H}$ dan 1 hari setelah hari H. Ketika melakukan pantawan, setelah tiba di atas rumah, tuan rumah akan menanyakan pada bujang ngantat atau gadis ngantat tentang si pengantin, bujang ngantat atau gadis ngantat yang akan menjelaskan. Pertanyaan tuan rumah biasanya mengenai kedua pengantin, misalnya "ia anak siapa?", "berapa bersaudara?", "anak ke berapa? ". Pertanyaan tersebut tidak dijawab oleh kedua pengantin, tetapi bujang ngantat atau gadis ngantat. Idealnya seorang bujang ngantat atau gadis ngantat harus tahu tentang keluarga si pengantin.

Pada masa lalu bujang dan gadis ngantat dipilih oleh jurai tue dengan mempertimbangkan berbagai kriteria. Beberapa kriteria dimaksud seperti usia, kecakapan, dan wawasan. Dari segi kepribadian, kriteria yang ditetapkan oleh tuo jurai adalah:

1. Peralah (mudah disuruh),

2. Tahu sopan santun,

3. Bermuka manis berlidah pasih

Kriteria tersebut menggambarkan seseorang yang siap membantu memenuhi kebutuhan pengantin baik dari kebutuhan pakaian, makanan, minuman atau keperluan lainnya. Disamping itu, orang tersebut harus bisa memposisikan dirinya selama kegiatan sedekahan, dalam arti dapat berbicara sesuai dengan orang yang dihadapinya, hadir pada tempat yang dibutuhkan, dan melakukan aktivitasnya dengan wajar tanpa menyinggung perasaan orang lain atau aturan adat setempat. Bermuka manis berlidah pasih merupakan kriteria untuk orang yang selalu ceria dan ikhlas melakukan pekerjaannya serta mampu menjelaskan segala yang dipertanyakan dengan sebenarnya secara baik dan sopan.

Bujang dan gadis ngantat ini biasanya dipilih dari orang yang belum 
menikah. Sebelum hari pantawan, bujang dan gadis ngantat ini dibekali dengan tugas dan tanggung jawab selama mendampingi kedua mempelai. Bujang/gadis ngantat disebut juga inang pengantin atau pelayan pengantin. Idealnya jurai tuwe memilih seorang sebagai bujang ngantat. Selanjutnya bujang ngantat memilih beberapa pengiring bujang ngantat untuk mendampinginya. Pengiring ini bisa mencapai sepuluh orang. Bentuk tugas-tugas tersebut selain menemani dan membantu membawa perlengkapan kedua mempelai, bujang dan gadis ngantat juga bertugas mengenalkan kedua pengantin kepada keluarga yang didatangi ketika ada pertanyaan tuan rumah. Bujang dan gadis ngantat juga harus mengetahui keluarga pengantin. Jumlah bujang/gadis ngantat antara 2-4 orang, namun kini jumlah tersebut jauh lebih banyak dengan terlibatnya bujang dan gadis dari keluarga pengantin.

Selain gadis dan bujang ngantat, beberapa anak-anak juga turut mendampingi kedua pengantin. Namun demikian, tidak ada aturan anak-anak harus ikut dalam kegiatan pantawan. Keikutsertaan anak-anak dalam pantawan hanya untuk meramaikan suasana saja. Masa tugas bujang dan gadis ngantat adalah selama pesta. Mulai dari pantawan hingga sehari sesudah acara resepsi. Biasanya tiga hari sebelum hari $\mathrm{H}$ dan sehari sesudah hari $\mathrm{H}$.

Menurut Sataruddin (Wawancara tanggal 20 Juni 2018 di Kota Pagaralam), bujang/gadis ngantat pada masa saat ini bisa dipilih orang-orang yang dekat dengan pengantin. Hal ini memiliki sisi positifnya seperti ketika salah bisa ditegur dan ditunjukkan bagaimana yang benar tanpa ada rasa sakit hati, tidak ada lagi upaya adaptasi karena sudah sama-sama akrab. Namun ada sisi tidak baiknya ketika si pengantin tidak memahami tugas-tugas dan berperilaku sebagai bujang dan gadis nganta. Hal ini untuk menghindari
"Belamai" (Orang buta membimbing orang buta).

Pada masa lalu, pakaian bujang dan gadis ngantat harus lebih baik dari pakaian pengantin, yaitu pakai kain sarung atau kain gebeng, kemeja, jas dan memakai peci, serta memakai sandal (tidak memakai sepatu). Pakaian bujang dan gadis ngantat berbeda dengan pakaian pengantin yang memakai gitar kepodang atau bulang (wawancara dengan Firman dan Sataruddin, 20 Juni 2018 di Kota Pagaralam). Namun demikian, berbeda dengan saat dilakukan penelitian lapangan, pakaian pengantin dan bujang serta gadis ngantat terlihat sangat sederhana. Pengantin perempuan menggunakan pakaian adat sederhana, sedangkan pengantin laki-laki menggunakan kemeja putih, jas, kopiah, dan sandal. Hal yang sangat mencolok perbedaannya terlihat pada bujang dan gadis ngantat, kedua pendamping pengntin ini hanya berpakaian seadanya (pakaian harian) dan tidak menunjukkan bahwa mereka sedang bertugas mendampingi pengantin. Hal ini tentu sangat berbeda dengan penjelasan di atas. Berdasarkan penuturan bujang dan gadis ngantat, tidak ada keharusan penggunaan pakaian tertentu untuk mendampingi pengantin selama pantawan, yang penting sopan. Orang tua maupun tokoh adat setempat juga tidak ada yang menegur penampilan mereka karena hal tersebut sudah dianggap biasa oleh masyarakat setempat. Setelah selesai bertugas, gadis dan bujang ngantat akan mendapat penghargaan berupa pakaian atau kain milik si pengantin dan dibekali dengan berbagai jenis kuliner untuk dibawa pulang. 


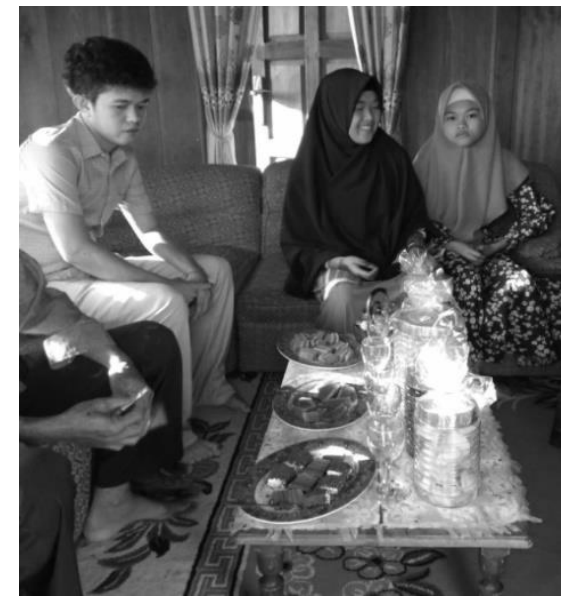

Gambar 1. Bujang dan Gadis Ngantat Sumber: Dokumen Penulis.

Prosesi pantawan bunting diawali dengan bunting betine (pengantin wanita) menjemput bunting lanang (pengantin laki-laki). ${ }^{5}$ Bunting betine mengajak bunting lanang mengunjungi seluruh rumah kerabat pengantin wanita sesuai dengan informasi yang telah diberikan. Menurut pengakuan Tina Julita (bunting betine), sebenarnya dia tidak tahu rumah siapa saja yang akan dikunjungi dan ia akan tahu setelah sampai di rumah pertama. Biasanya orang sekitar akan menginformasikan rumah-rumah yang akan dikunjungi sambil berjalan. Namun demikian, rumah yang paling pertama dikunjungi adalah rumah yang terdekat jaraknya dengan rumah orang tuanya.

Sesampai di rumah yang dituju, tuan rumah sudah menunggu di depan rumah atau di pintu rumah ketika melihat pengantin berjalan menuju rumahnya. ${ }^{6}$ Pengantin akan mengucapkan salam secara Islam yang dijawab oleh tuan rumah, lalu

\footnotetext{
${ }^{5}$ Bunting lanang sudah tiba di rumah bunting betine satu jam sebelum pantawan dimulai dengan berpakaian lengkap.

6 Tuan rumah yang menyambut umumnya adalah ibu-ibu dan anak-anak tuan rumah. Sedangkan Bapak-Bapak atau suami tidak di rumah karena ikut bekerja di tempat sedekahan sesuai dengan tanggung jawabnya sebagai kerabat pelaksana hajatan.
}

bersalaman. Tuan rumah mempersilahkan pengantin dan rombongan untuk masuk dan mencicipi hidangan, sementara tuan rumah tetap berada di luar atau ikut masuk tetapi sesaat kemudian meninggalkan ruang tamu tempat hidangan disediakan. Dengan kondisi ini, praktis yang ada di ruang tamu dan mencicipi hidangan adalah rombongan pengantin. ${ }^{7}$ Menurut tuan rumah, hal ini dilakukan karena menjaga agar si pengantin yang dipantaw tidak merasa sungkan untuk makan.

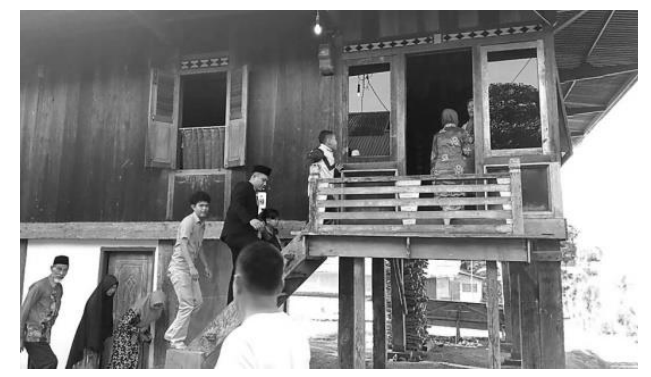

Gambar 2. Bunting dan Pendamping Memasuki Rumah

Sumber: Dokumen Penulis.

Kondisi seperti ini menurut Ahmad Bastari Suan (korespondensi via e-mail) biasanya terjadi pada tuan rumah (orang yang mantaw) yang sudah jauh hubungan kekerabatan dengan keluarga yang sedekahan atau mungkin sekadar toleransi sedusun atau sekampung saja. Terkadang damping ghumah jauh usuran (tetangga dekat yang bukan kerabat atau bukan kerabat dekat). Tuan rumah (yang mantaw) memang tidak makan bersama dengan orang yang dipantaw. Jika tuan rumah masih kerabat dekat dari yang sedekah (yang hajatan/helatan/kenduri), maka tuan rumah itu (biasanya para perempuan, mungkin nenek, ibu, bibi, dan anak/ cucu gadis) mendampingi bunting yang dipantaw sambil menjelaskan hubungan kekerabatan dan antara bertutur saja, sesuai konsep tujuan pantawan (dalam hal ini pantawan-bunting). Penjelasan (asumsi) Ahmad Bastari Suan tersebut berbeda

\footnotetext{
${ }^{7}$ Dari 50 rumah yang didatangi oleh pengantin, hanya ada 3 tuan rumah ikut menemani pengantin laki-laki maupun pengantin wanita.
} 
dengan penjelasan Tina Julita (bunting betine) yang menyatakan bahwa rumah yang dikunjungi adalah kerabat dekatnya karena ada juga tetangga dekat yang tidak dikunjungi, artinya yang mantaw bunting hanyalah sebatas keluarga dekat. Dari penjelasan tersebut bisa disimpulkan bahwa terjadi perubahan pada pelaksanaan pantawan karena tuan rumah tidak lagi menemani bunting ketika mencicipi hidangan yang disediakan dan dengan sendirinya tidak ada lagi komunikasi di antara mereka sebagaimana idealnya pelaksanaan pantawan.

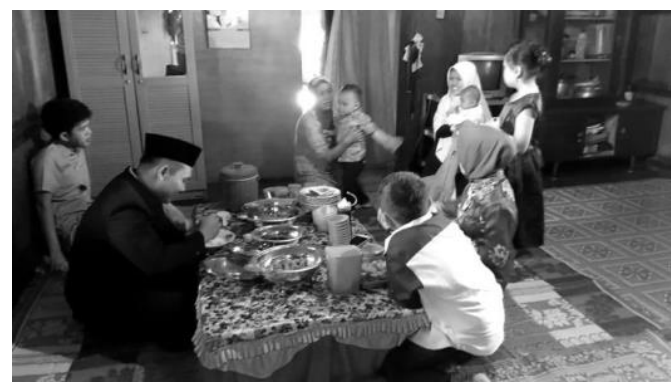

Gambar 3. bunting menikmati hidangan Sumber: Dokumen Penulis.

Hidangan yang disediakan di dalam rumah umumnya adalah kue-kue dan sebagian rumah menyediakan makanan berupa nasi beserta lauk pauknya. Tidak ada keharusan jenis makanan yang dihidangkan pada saat pantawan, semua tergantung pada kemampuan si tuan rumah.

Beberapa makanan dan minuman ringan yang umumnya dihidangkan pada saat pantawan adalah:

1. Buburnasi dan bermacam bubur (bubugh/bubuw);

2. Bajik (wajik);

3. Belinak (semacam bajik);

4. Dudul-padiberam (dodol ketam-itam dan bermacam dudul);

5. Jalir-perenggi (kolak labu);

6. Juwadah basah (bolu-pendan);

7. Juwadah besak/mulu (bolu)

8. Keripik abang (keripik merah;

9. Lemang, bermacam lemang;
10. Pisang-guring (pisang digoreng), biasanya jenis pisang-sabe (pisang tembatu);

11. Serawe (kolak pisang dan atau ketan);

12. Tapay padiberam (tapai ketan-itam).

Idealnya hidangan yang disajikan pada saat pantawan adalah makanan adat, tetapi tergantung pada kemampuan si tuan rumah menyajikan secara lengkap atau sebagian. Beberapa menu berupa makanan adat Besemah adalah:

1. Bajik,

2. Belinak,

3. Dudul padiberam,

4. Juwadah basah,

5. Juwadah besak/mulu,

6. Keripik abang (biasanya mantaw jeme njenguk,pentakziah, pelayat dari dusun lain),

7. Lemang

8. Pisang-guring

9. Tapay padi beram (pantawan Riaye, Riaye Puwase Idul Fitri, dan Riaye Puwase Hari Raya Puasa Idul Fitri dan Riaye Aji", Hari Raya Haji , Idul Adha).

Keharusan dalam pantawan bunting adalah pengantin dan seluruh rombongan mencicipi hidangan yang telah disediakan oleh tuan rumah. Hal ini merupakan penghargaan terhadap tuan rumah karena akan dianggap sombong jika ada tamu yang tidak mencicipi hidangan tersebut.

Walaupun tuan rumah tidak mendampingi bunting pada saat datang ke rumahnya, jika bunting dan rombongan tidak masuk atau tidak mencicipi hidangan yang telah disediakan akan menimbulkan prasangka yang tidak baik bagi bunting dan rombongan. Prasangka yang tidak baik tersebut bisa berupa hidangannya dianggap tidak enak, rumahnya tidak layak untuk rombongan, atau prasangka negatif lainnya.

Tuan rumah tidak melayani pengantin ataupun rombongan selama rombongan di rumah yang didatangi. Sebelum rombongan tiba, seluruh hidangan baik makanan, minuman, cuci 
tangan, sendok, tissu (lap tangan), dan keperluan lainnya sudah disediakan. Dengan demikian tidak ada lagi alasan pengantin atau anggota rombongan untuk meminta sesuatu. Hal tersebut disebabkan tuan rumah umumnya tidak hadir di ruangan yang sama. Alasan ini pulalah yang menyebabkan segala keperluan rombongan dipersiapkan sedemikian rupa.

Tuan rumah yang mantaw akan menghidangkan makanan dan minuman sebaik mungkin untuk menanamkan kesan positif bagi rombongan. Hal ini menimbulkan kesan adannya "persaingan" antar tuan rumah. Semakin banyak dan semakin mahal variasi hidangan yang disajikan, akan dianggap lebih mampu dari yang lain. Kesan lain dari variasi hidangan adalah keseriusan tuan rumah dalam melayani pengantin karena adanya kedekatan emosional atau hubungan kerabat yang sangat dekat.

Selama prosesi pantawan bunting, bujang dan gadis ngantat tidak terlalu terlihat fungsi dan perannya. Mereka hanya mengikuti ke mana pengantin pergi tanpa harus memberikan penjelasan kepada tuan rumah tentang pengantin pria (yang dipantaw). Salah satu tugas gadis ngantat adalah memperbaiki posisi sepatu pengantin pada saat naik tangga rumah yang awalnya mengarah ke dalam (pintu/tangga) dibalik menjadi arah ke jalan. Hal ini dilakukan agar memudahkan pengantin memasang sepatu setelah turun dari rumah. Fungsi bujang dan gadis ngantat sebagai penyambung informasi tentang penganting bagi tuan rumah tidak lagi nampak karena si bujang dan gadis ngantat memang tidak dibekali dengan pengetahuan tentang hal tersebut. Selain itu, tidak ada dialog antara tuan rumah dengan rombongan.

Proses pantawan bunting dianggap selesai jika seluruh rumah yang mantaw sudah dikunjungi. Tidak ada alasan bagi bunting untuk menolak mendatangi rumah karena akan berdampak kurang baik bagi hubungan kekerabatan mereka.

\section{Pertukaran Sosial}

Ritzer dan Smart (2012: 516-517) menjelaskan unsur dasar dari pertukaran sosial yaitu aktor, sumber daya, struktur, dan proses. Aktor adalah orang-orang yang terlibat dalam pertukaran sosial tersebut baik berupa individu maupun kelompok atau entitas khusus lainnya. Setiap aktor memiliki sumber daya yang menjadi modal untuk melakukan pertukaran sosial. Aktor yang melakukan pertukaran melalui sumber daya yang ada akan menanggung biaya agar dapat memberikan hasil kepada aktor lain. Biaya yang dimaksudkan dalam hal ini bisa berupa pengorbanan waktu, tenaga, materi, atau dalam bentuk prilaku (seperti senyum, berbicara dengan baik, dan lain-sebagainya). Dijelaskan juga bahwa dalam pertukaran sosial terdapat struktur berupa ketergantungan timbal baik. Beberapa bentuk struktur tersebut ada yang berupa pertukaran langsung (direct exchange), pertukaran umum (general exchange), dan pertukaran produktif (productive exchange). Pertukaran langsung adalah pertukaran yang hasilnya tergantung pada relasi antara dua aktor tersebut. Pertukaran umum terjadi antara dua atau lebih aktor sehingga hasilnya tidak bisa dirasakan langsung oleh masingmasing aktor. Ada ketergantungan timbal balik, hasilnya tidak serta merta diperoleh dari si B ke si A tetapi bisa jadi melalui si $\mathrm{C}$ yang juga melakukan pertukaran dengan si B. Pertukaran produktif adalah setiap aktor melakukan pertukaran secara bersama agar mendapat hasil dari aktor lain. Unsur pertukaran sosial yang terakhir adalah proses pertukaran, yaitu interaksi yang terjadi dalam struktur pertukaran, kesempatan untuk melakukan pertukaran dan jika pertukaran sudah terbalas, maka telah terjadi transaksi. Transaksi yang terjadi terus menerus menghasilkan relasi pertukaran.

Mengacu pada penjelasan tersebut, tradisi pantawan bunting pada suku bangsa Basemah merupakan pertukaran sosial yang berlangsung antara aktor-aktor di lingkungan tetangga, kerabat, dan rurah. 
Aktor-aktor dalam pantawan adalah tuan rumah yang menyediakan makanan dan minuman (yang mantaw), aktor berikutnya adalah bunting (lanang dan betine), dan bujang dan gadis ngantat.

Tuan rumah yang umumnya adalah ibu-ibu memberikan sumber daya yang dia miliki kepada bunting dan bujang dan gadis ngantat. Sumber daya yang diberikan sebagai biaya dari interaksi yang terjadi berupa makanan dan minuman, meluangkan waktu menunggu rombongan datang, menghabiskan biaya dalam bentuk uang untuk membeli kebutuhan pantawan, sumber daya berupa perasaan yang harus melayani tamu dengan muka manis, senyum ramah, dan sebisa mungkin membuat nyaman dan senang tamu yang datang.

Dari pihak bunting sendiri sebagai aktor juga mengeluarkan sumber daya yang ia miliki agar bisa berinteraksi dengan tua rumah. Sumber daya yang dikeluarkan adalah perasaan harus selalu terlihat bahagia, senyum, dan bertutur sapa dengan sopan, meluangkan waktu, dan rela lelah mendatangi semua rumah yang ingin mantaw calon pengantin laki-laki atau prempuan. Demikian juga bagi bujang dan gadis ngantat tidak terlepas dari pengorbanan terhadap sumber daya yang ia miliki seperti waktu yang terpakai, berpenampilan sebaik mungkin, berbicara dengan baik, siap membantu bunting dalam segala keperluannya.

Dalam tulisan ini yang dianalisis adalah antara tuan rumah dan bunting. Sedangkan antara bujang dan gadis ngantat dengan tuan rumah tidak memiliki hubungan langsung karena pada dasarnya bujang dan gadis ngantat berhubungan dengan bunting. Hubungan antara bujang dan gadis ngantat dengan bunting tidak dapat dikatakan sebagai pertukaran sosial karena hubungan di antara mereka telah dianggap selesai ketika prosesi pantawan bunting selesai dan bujang dan gadis ngantat telah menerima cendramata sebagai ganjaran (reward) dari apa yang telah diberikan kepada bunting.
Struktur pertukaran yang terjadi pada pantawan bunting adalah pertukaran umum yang tidak langsung. Artinya, baik tuan rumah, maupun bunting tidak mengetahui kapan ia akan mendapatkan balasan atau ganjaran dari apa yang telah ia pertukarkan. Namun demikian, bagi tuan rumah, sesuai dengan tujuan dari pantawan bunting adalah untuk lebih mengenal calon pengantin serta memperkenalkan hubungan kekerabatan di antara mereka. Oleh sebab itu, ganjaran yang diharapkan dari tuan rumah adalah si bunting telah mengenal kerabat dan hubungan kekerabatan di antara mereka beserta hak dan kewajiban yang melekat dalam hubungan kekerabatan tersebut.

Dengan pertukaran sosial, hubungan antara bunting dengan tuan rumah tetap terikat yang oleh Ahmad Bastari Suan diistilahkan sebagai "kontrak seumur hidup". "Kontrak" ini adalah kewajiban tolong menolong pada bidang ekonomi, adat, atau kepentingan lainnya di hari-hari yang akan datang.

Tabel 1 Analisis Pertukaran Sosial Pada Pantawan Bunting

\begin{tabular}{llll}
\hline \multirow{2}{*}{ Aktor } & \multicolumn{1}{c}{$\begin{array}{c}\text { Sumber } \\
\text { Daya }\end{array}$} & Struktur & Proses \\
\hline \multirow{4}{*}{ Tuan } & Hidangan & & \\
& makan dan & General & \\
Rumah & Perasaan, & Ketergant & Transaksi \\
& Waktu, & ungan & \\
& Ekonomi & timbal & \\
& (Pembiayaa & balik & \\
& n) & & \\
& & General & \\
& & Exchange, & \\
& & Direct & \\
& Perasaan, & Exchange, & Transaksi \\
Bunting & Waktu, & Ketergantu & \\
& Penampilan & ngan & \\
& & timbal & \\
& & balik & \\
\hline
\end{tabular}

Sumber: Analisa Data Lapangan

Sebagian besar masyarakat Besemah cenderung ingin menghapus tradisi pantawan dengan alasan tidak ekonomis, tidak praktis, dan tidak modern. Alasan 
ekonom biasanya terkait dengan besarnya biaya yang dibutuhkan oleh tuan rumah untuk menyediakan hidangan dalam menyambut tamu (bunting). Jika dalam satu pantawan saja bisa mengeluarkan biaya $\mathrm{Rp} 500.000,-$ dan apabila ada dua atau tiga pantawan, tuan rumah akan mengeluarkan dana Rp1.000.000,- sampai Rp1.500.000,-. $\quad$ Alasan tidak praktis karena mereka melihat pantawan bunting sangat merepotkan baik bagi pengantin, maupun tuan rumah yang mantaw. Seolaholah tidak ada manfaatnya bagi kedua belah pihak. Alasan ketiga adalah pantawan dianggap sudah ketinggalan zaman dan tidak mengikuti perkembangan saat ini. Akibat dari anggapan ini, di wilayah Kota Pagaralam hanya beberapa desa saja yang masih melaksanakan tradisi pantawan bunting. Itu pun tidak lagi dilaksanakan dengan ideal seperti pada masa lalu.

Kecenderungan

penolakan masyarakat Besemah terhadap tradisi ini karena masyarakat tidak memahami substansi dari tradisi pantawan bunting. Masyarakat hanya melihat dari aspek fisik dan yang tampak, mereka tidak melihat bahwa ada pertukaran sosial yang terjadi di antara kedua belah pihak. Dengan pertukaran sosial ini, interaksi kedua belah tetap terjalin dengan segala hak dan kewajibannya.

\section{PENUTUP}

Tradisi pantawan

bunting merupakan salah satu cara untuk tetap menjalin tali silahturahmi sehingga ikatan kekeluargaan tidak putus. Pelaksanaan pantawan secara ekonomi membutuhkan biaya yang tidak sedikit. Pelaksanaan pantawan dianggap menghamburkan uang atau kegiatan yang tidak ekonomis karena hanya memberikan makan dari tuan rumah kepada pengantin tanpa ada timbal balik yang diberikan oleh pengantin kepada tuan rumah. Bagi sebagian masyarakat Besemah hal ini dianggap kegiatan yang merugikan dan lambat laun mulai ditinggalkan.
Jika dilihat dari teori pertukaran sosial, pantawan bunting merupakan proses "jual beli" atau transaksi antara pihak tuan rumah dengan pengantin. Si tuan rumah mengharapkan ada timbal balik dari sumber daya yang diberikannya kepada si pengantin berupa ganjaran positif seperti kesediaan membantu dan terlibat dalam kegiatan keluarga tersebut. Struktur pertukaran sosial yang berlangsung adalah pertukaran sosial yang tidak langsung dan bersifat timbal balik. Hal ini berarti tuan rumah maupun pengantin tidak langsung mendapatkan ganjaran dari sumber daya yang telah diberikannya dalam proses interaksi. Ganjaran yang didapat bisa saja diterima dari pihak ketiga atau lainnya.

Dari aspek sosial budaya, pantawan bunting memiliki manfaat yang sangat penting dalam melestarikan nilai-nilai budaya maupun mempererat hubungan sosial, baik dalam anggota kerabat maupun dalam lingkungan sosial. Agar tradisi ini dapat tetap bertahan, masyarakat telah menyederhanakan pelaksanaan dengan tidak mengharuskan menghidangkan makananan adat. Hidangan yang disajikan tergantung kepada kemampuan tuan rumah namun tidak menghilangkan makna dari tradisi pantawan bunting itu sendiri.

Dengan melihat respon masyarakat dalam melaksanakan tradisi pantawan bunting yang terkesan terpaksa, perlu kiranya para tokoh adat setempat merumuskan kembali konsep pelaksanaan tradisi pantawan bunting yang sesuai dengan kondisi masyarakat saat ini, sehingga secara nilai-nilai budaya tidak hilang tetapi proses tetap berjalan. Pihak Pemerintah Kota Pagaralam juga diharapkan melakukan sosialisasi tentang pentingnya penanaman dan pelestarian nilai tradisi sehingga menumbuhkan kesadaran di masyarakat. 


\section{DAFTAR SUMBER}

\section{Jurnal, Makalah, dan Skripsi}

Ambarwati, Retno Tri dan Hesti Asriwandari. "Tradisi Sinoman Sebagai Sistem Pertukaran Sosial Di Dalam Pelaksanaan Pesta Pernikahan Adat Jawa (Studi Pada Masyarakat Transmigrasi Di Desa Pasir Jaya Kecamatan Rambah Hilir Kabupaten Rokan Hulu)" dalam Jurnal Online Mahasiswa (JOM) Fisip Universitas Riau, Vol. 1. No. 1 Tahun 2014. Hlm 115.

Arios, Rois Leonard. "Permukiman Tradisional Orang Basemah di Kota Pagaralam" dalam Jnana Budaya Volume 19, Nomor 2, Agustus 2014. Hlm $183-198$.

Asrin, Sudjarwo, dan Pargito. "Tata Cara Budaya Perkawinan Suku Pasmah di Padang Guci” dalam Jurnal Studi Sosial Vol. 4 No. 3 Tahun 2016. Hlm 17-30.

Firnanda, Anissa. 2018. "Tradisi Pantauan sebagai Bentuk Pluralisme antar Dua Suku di Desa Lawang Agung Kecamatan Kedurang Bengkulu Selatan". Makalah Pada Lomba Karya Tulis Ilmiah Tingkat SLTA Se Propinsi Sumatera Barat, Bengkulu, dan Sumatera Selatan yang diselenggarakan oleh BPNB Sumatera Barat.

Gunawardi. 2016. "Persepsi Masyarakat Terhadap Pertukaran Sosial Pada Kenduri di Gampong Alue Sungai Pinang Kecamatan Jeumpa Kabupaten Aceh Barat Daya". Skripsi Program Studi Sosiologi FISIP Universitas Teuku Umar Aceh.

\section{Buku}

Afrizal. 2014.

Metode Penelitian Kualitatif: Sebuah Upaya Mendukung Penggunaan Penelitian Kualitatif Dalam Berbagai Disiplin Ilmu. Jakarta: Raja Grafindo Persada.

Damsar, 2015.

Pengantar Teori Sosiologi. Jakarta: Prenadamedia Group.

Mulyana, Dedy 2008.

Metodologi Penelitian Kualitatif: Paradigma Baru Ilmu Komunikasi dan
Ilmu Sosial Lainnya. Bandung: Remaja Rosdakarya.

Ritzer, George dan Barry Smart. 2012. Handbook Teori Sosial. Jakarta: Nusa Media.

Sakai, Minako. 2017.

Kacang tidak Lupa Kulitnya: Identitas Gumay, Islam dan Merantau di Sumatera Selatan. Jakarta: Yayasan Pustaka Obor Indonesia.

Scott, John. 2012

Teori Sosial: Masalah-Masalah Pokok dalam Sosiologi. Yogyakarta: Pustaka Pelajar.

Suan, Ahmad Bastari, dkk. 2007a.

Tata Cara Adat Perkawinan Sukubangsa Besemah di Sumatera Selatan. Palembang: Dinas Pendidikan Nasional Propinsi Sumatera Selatan.

Suan, Ahmad Bastari, dkk. 2007b. Atung Bungsu: Sejarah Asal Usul Jagat Besemah. Palembang: Pesake dan Pemerintah Kota Palembang.

Suan, Ahmad Bastari, dkk. 2008.

Besemah: Lampik Mpat Merdike Duwe. Palembang: Pesake dan Pemerintah Kota Palembang.

\section{Informan}

Firman (54 tahun).

Ketua lembaga adat Kota Pagaralam. Wawancara pada 20 Juni 2018.

Julita, Tina (26 tahun). Pengantin. Wawancara pada 20 Juni 2018 di Pagaralam, via telepon pada 30 Juli 2018.

Kasim (70 tahun).

Tokoh adat dan ketua Yayasan Dempo Lestari. Wawancara pada 20 Juni 2018.

Ola, Sataruddin Cik (82 tahun).

Tokoh adat dan mantan ketua lembaga adat Kota Pagaralam. Wawancara pada 20 Juni 2018.

Suan, Ahmad Bastari (73 tahun).

Penulis sejarah dan budaya Basemah. Wawancara pada 2 Maret 2018 di Palembang, 23 Juni 2018 di Pagaralam, dan via telepon 5 Maret 2018. 